This item was submitted to Loughborough's Research Repository by the author.

Items in Figshare are protected by copyright, with all rights reserved, unless otherwise indicated.

\title{
Dealing with multiple hazards and threats on cultural heritage sites: An assessment of 80 case studies
}

PLEASE CITE THE PUBLISHED VERSION

https://doi.org/10.1108/DPM-08-2018-0245

\section{PUBLISHER}

Emerald

VERSION

AM (Accepted Manuscript)

\section{PUBLISHER STATEMENT}

This work is made available according to the conditions of the Creative Commons Attribution-NonCommercialNoDerivatives 4.0 International (CC BY-NC-ND 4.0) licence. Full details of this licence are available at: https://creativecommons.org/licenses/by-nc-nd/4.0/

\section{LICENCE}

CC BY-NC-ND 4.0

\section{REPOSITORY RECORD}

Bosher, Lee, Dowon Kim, Takeyuki Okubo, Ksenia Chmutina, and Rohit Jigyasu. 2019. "Dealing with Multiple Hazards and Threats on Cultural Heritage Sites: An Assessment of 80 Case Studies". figshare. https://hdl.handle.net/2134/38207. 


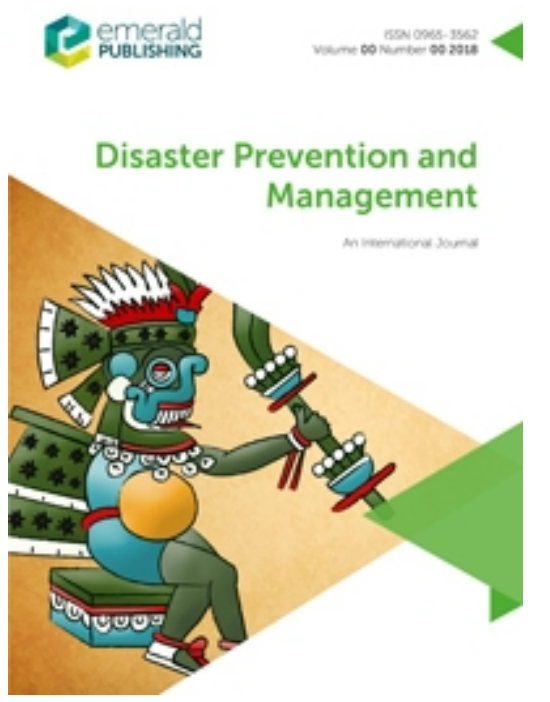

\section{Dealing with multiple hazards and threats on cultural} heritage sites: An assessment of $\mathbf{8 0}$ case studies

\begin{tabular}{|r|l|}
\hline Journal: & Disaster Prevention and Management \\
\hline Manuscript ID & DPM-08-2018-0245.R1 \\
\hline Manuscript Type: & Research Paper \\
\hline Keyword: & Cultural Heritage, Disaster Risk Management, resilience, Case studies \\
\hline \multicolumn{2}{|r}{} \\
\hline
\end{tabular}

\section{SCHOLARONE ${ }^{\text {M }}$ Manuscripts}




\title{
Dealing with multiple hazards and threats on cultural heritage sites: an assessment of 80 case studies Lee Bosher, Dowon Kim, Takeyuki Okubo, Ksenia Chmutina, \& Rohit Jigyasu
}

\begin{abstract}
Purpose: Cultural heritage $(\mathrm{CH})$ sites are not only important components of a country's identity but can also be important drivers of tourism. However, an increasing number of extreme events associated with the impacts of climate change, natural hazards and human-induced threats are posing significant problems in conserving and managing cultural heritage worldwide. Consequently, improved climate change adaptation and enhanced hazard/threat mitigation strategies have become critical (but to-date under researched) considerations. This paper aims to identify the key hazards and threats to cultural heritage sites, the most common types of risks to $\mathrm{CH}$ and the strategies being adopted to mitigate or even eradicate those risks.
\end{abstract}

Design/methodology: This paper reviews $80 \mathrm{CH}$ case studies from around the world, which have been presented at a UNESCO International Training Course between 2006-2016. The case studies cover 45 different countries and provide practical insights into the key challenges being encountered in a variety of 'at risk' locations.

Findings: The analysis assesses the key natural hazards and human-induced threats to the sites, an overview of the typical impacts to the tangible components of heritage and identifies the types of strategies being adopted to mitigate the risks, some of which could be transferred across cultural and geographical contexts.

Originality: The paper provides a wealth of useful information related to how challenges faced by $\mathrm{CH}$ sites might be addressed in the future

Keywords: cultural heritage, resilience, disaster risk management

Acknowledgement: This study was funded in part by a Daiwa Foundation Grant (14/15-35), a British Academy Visiting Fellowship (VF1 1102103) and an 'International Collaboration' grant from Loughborough University. We would like to thank all the participants that have taken part in the ITC courses since 2006 for bringing their experiences and insights from cultural heritage sites across the world.

\section{INTRODUCTION}

Recent disasters such as earthquakes in Nepal (2015), cyclones in the Philippines (2014), fires in Lijiang, China (2013 and 2014) and the devastating tsunami along the east coast of Japan (2011), have caused enormous loss of life, property and cultural heritage. These disasters are just a few examples (of many) that have demonstrated the extent to which Cultural Heritage $(\mathrm{CH})$ is highly vulnerable to the impacts of a wide range of natural hazards and human induced threats. Thus, it is increasingly being recognised how important it is to undertake proactive measures that can reduce risks to $\mathrm{CH}$ from these catastrophic events through adequate mitigation and preparedness (Jigyasu et al., 2013). Additionally, in the post disaster phase, the challenge is how to salvage heritage properties, which are at risk of demolition and to assess their damage. The long-term challenge during the recovery phase is how to repair and retrofit affected properties, sites and assets and undertake reconstruction that respects tangible as well as intangible heritage values (Ravankhah et al. 2017).

In 2007 UNESCO adopted its 'Strategy for Reducing Risks at World Heritage Properties', not only to enhance World Heritage sites protection from natural hazards, but also to advocate the importance of $\mathrm{CH}$ in international developmental agendas. The document clearly emphasises "strengthen[ing] support within relevant global, regional, national and local institutions for reducing risks at World Heritage properties" as one of the main objectives, with a view to "promote cultural and natural heritage, and its potential positive role for disaster reduction as part of sustainable development..." (UNESCO, 2007). Subsequently, a collaborative paper on 'heritage contributions to resilience', prepared by ICOMOS-ICORP, UNISDR, UNESCO, and ICCROM, was presented to the fourth session of the Global Platform on Disaster Risk Reduction in Geneva 
in 2013 (Jigyasu et al., 2013). Apart from highlighting CH issues in reducing disaster risks, it aimed to draw the attention of the global community of disaster risk reduction professionals to $\mathrm{CH}$, and later to stress $\mathrm{CH}$ in upcoming international agendas.

The UN's report for the Post-2015 UN Development Agenda "Realising the Future We Want for All", highlights the importance of disaster risk reduction and resilience within the context of environmental sustainability; one of the four core dimensions of sustainability (UN, 2012). The concepts of sustainability and resilience highlight the importance of long-term effects and of taking a holistic and systematic view of highly interconnected variables. Goal 11 of the 2030 Agenda for Sustainable Development - "make cities and human settlements inclusive, safe, resilient and sustainable" - explicitly acknowledges 'Heritage' in target 11.4: "strengthen efforts to protect and safeguard the world's cultural and natural heritage" (UN, 2015, p.18). Following the Sustainable Development Goals (SDGs), the integration of the concept of 'Cultural Heritage' into disaster resilience has been emphasised in the UN's Sendai Framework for Disaster Risk Reduction (SFDRR) 2015-2030, ${ }^{1}$ particularly within Priority for Action 1 'Understanding disaster risk and Priority', and within Action 3 'Investing in disaster risk reduction for resilience' (UNISDR, 2015). While the abovementioned efforts have helped to promote the importance of risk management of heritage as well as the potential roles of heritage in contributing to disaster resilience, such a laudable aim may in reality pose a number of problems in relation to competing priorities, disciplinary boundaries and ultimately operational effectiveness, in particular when it comes to implementation at the national and local levels (Ravankhah et al. 2017).

A key factor indicating the need to increase the resilience of heritage sites is the fragility of their historic fabric and higher vulnerability (i.e. due to ageing materials, limited critical infrastructure and urban density) to natural hazards and human-induced threats in comparison with contemporary urban areas, which typically have a higher response capacity (i.e. due to stricter/modern building codes, modern 'tested' materials and better access for emergency services). This paper reviews a wide range of 'heritage' case studies from around the world, which have been presented at the UNESCO International Training Course between 20062016, with the aim of identifying the key natural hazards and human-induced threats to the sites, the typical types of impacts to the tangible components of $\mathrm{CH}$ and to identify the types of strategies being adopted to mitigate or even eradicate the risks.

\section{CULTURAL HERITAGE SITES AT RISK}

$\mathrm{CH}$ sites that have withstood the test of time are becoming increasingly prone to the impacts of natural hazards (such as earthquakes, floods, cyclones) as well as human induced threats (such as vandalism, theft, arson and rapid urbanisation). For instance, Figure 1 illustrates how many UNESCO cultural heritage sites are located in seismically active areas. In the absence of any comprehensive legal framework for protection, $\mathrm{CH}$ sites are vulnerable not only to impending disasters but also during emergency and post disaster recovery phases (Jigyasu 2016). The major underlying causes for their increasing vulnerability are climate change, population growth, urbanisation and poverty, especially in developing countries (ibid).

Rapidly urbanising areas with rich cultural heritage such as Istanbul in Turkey, Kyoto in Japan, Mexico City in Mexico, Kathmandu in Nepal and Cairo in Egypt are located in seismically active zones and thus are highly vulnerable to disasters. Likewise, many of the World's oldest cities were established along rivers and coastlines, mainly for the benefits of drinking, food, transport, energy and industry that such locations can provide in abundance. However, these locations (such as Bangkok, London and Venice) tend to provide environments that are hazardous due to a broad range of flooding events related to unmanageable amounts of excess water (related to floods, storms and tsunamis).

\footnotetext{
1 The Sendai Framework for Disaster Risk Reduction 2015-2030 was adopted at the Third United Nations World Conference on Disaster Risk Reduction, held in March 2015 in Sendai, Japan.
} 


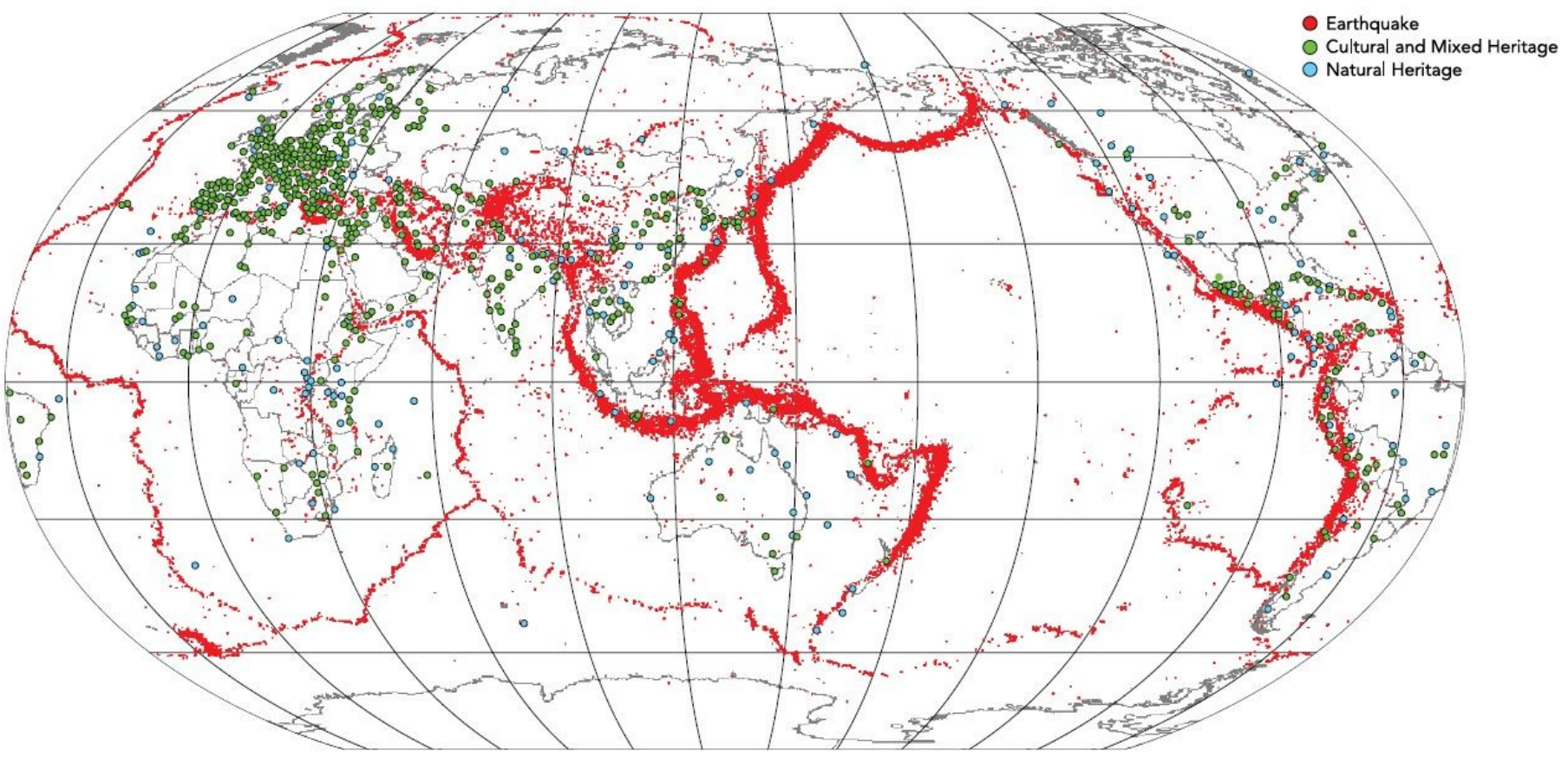

Figure 1: Earthquake risk of UNESCO heritage sites (Masuda et al. 2009)

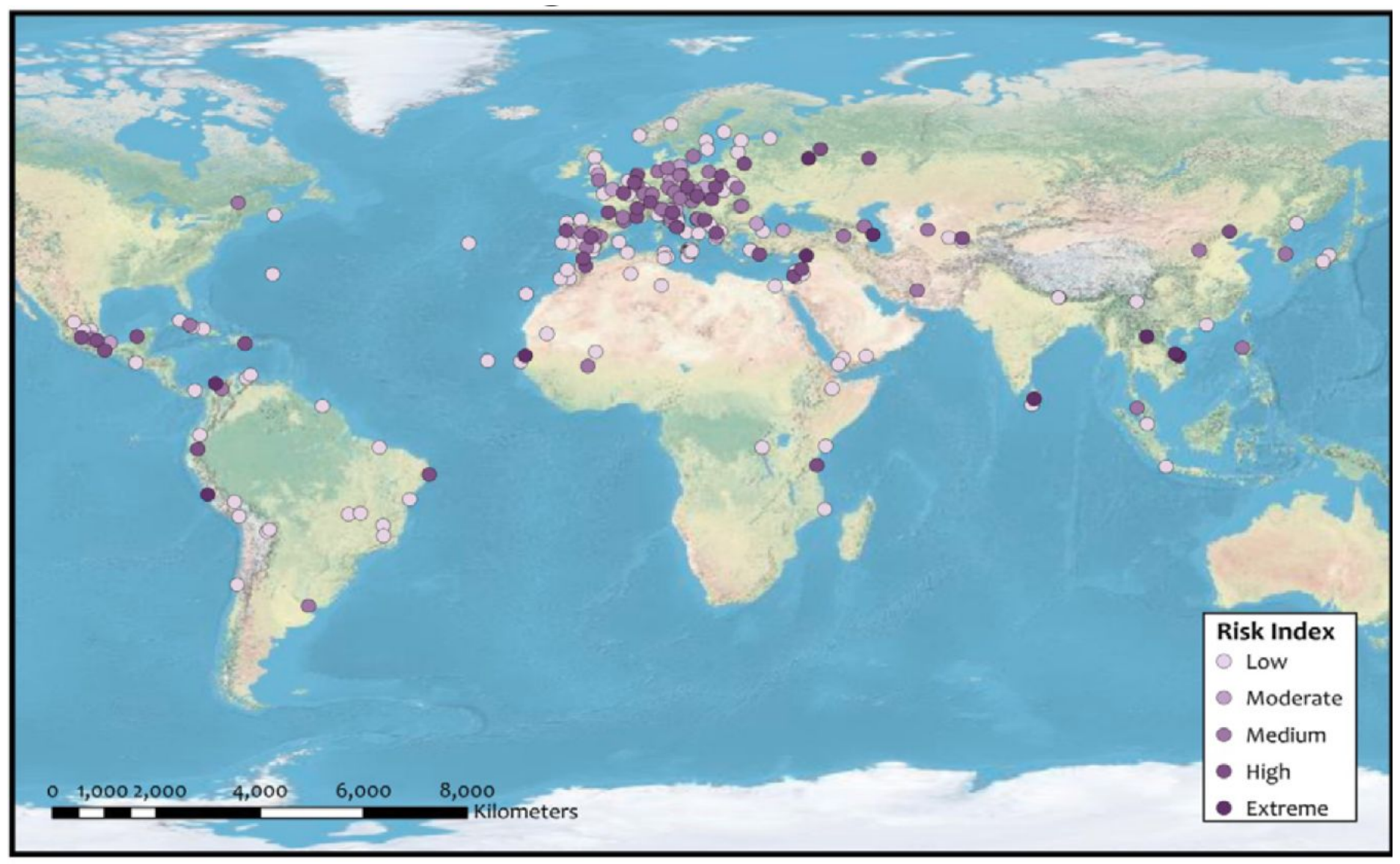

Figure 2: Flood risk of UNESCO heritage sites (Bigio et al., 2014) 


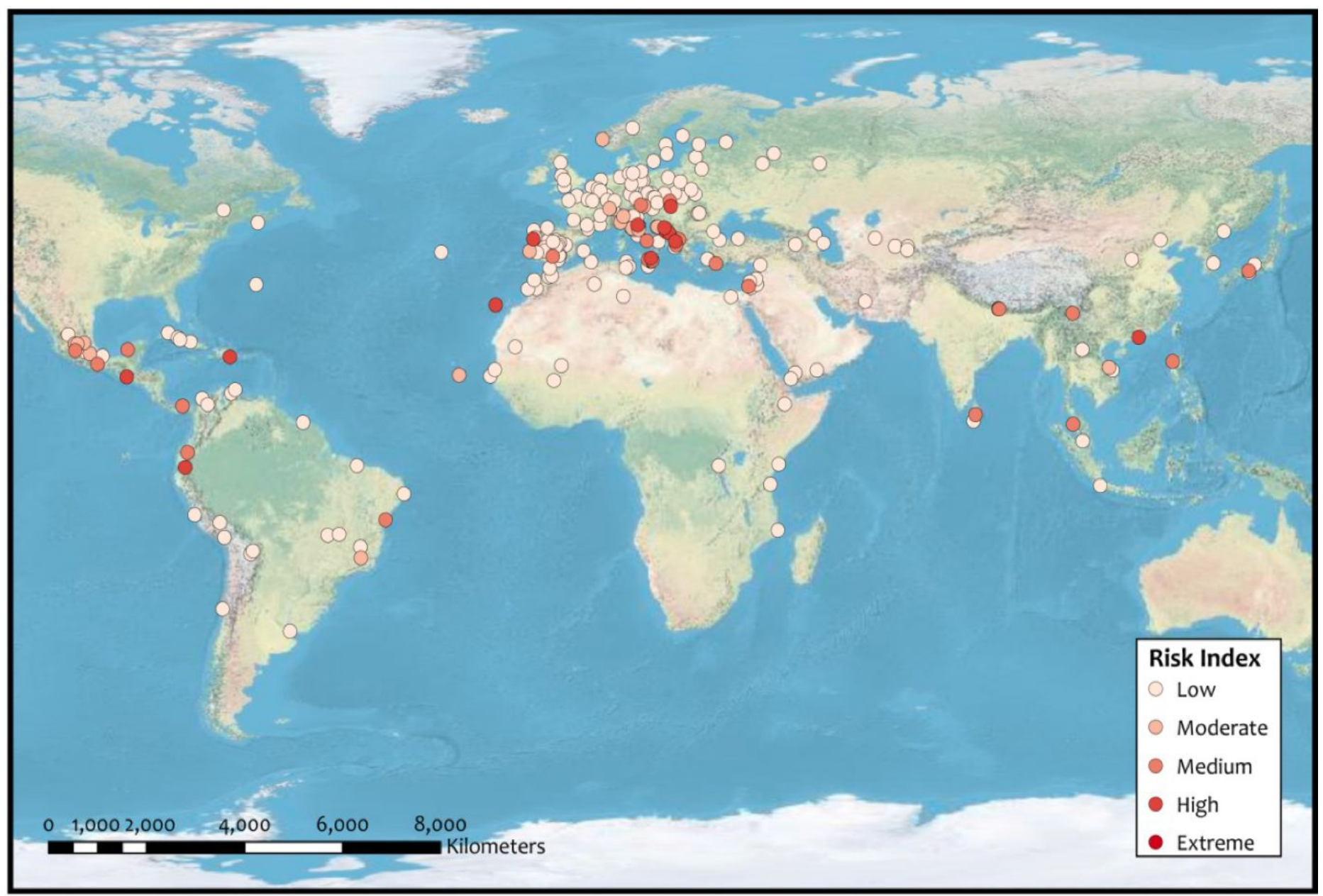

Figure 3: Landslide risk of UNESCO heritage sites (Bigio et al., 2014)

\section{MAKING HAZARD PRONE HERITAGE SITES MORE RESILIENT}

Recent policy frameworks (e.g. SFDRR and SDGs) are addressing the importance of Disaster Risk Management (DRM) in both the sustainability and resilience agendas. Despite a shift to more pro-active and pre-emptive approaches to managing disaster risk, DRM is still largely influenced by more reactive emergency management practices (UN, 2015). The term 'resilience', whilst being surrounded by various debates on its meaning, usefulness and characteristics (see Chmutina et al., 2016; Alexander, 2013; Bahadur et al., 2010), has become an integral part of DRM terminology and international agendas, as this concept captures the (arguably rather constrained) ability of a system to rebound or resume its original form after a stress or perturbation. However, the vagueness and malleability of the term 'resilience' has led to a variety of interpretations and applications, thus making the term politically successful in reconciling the interests of politicians and practitioners (Bosher, 2014). Within the context of DRM and as defined by the UNDRR, ${ }^{2}$ different approaches to resilience provide different levels of importance to the objectives of avoidance (avoid the shock), recovery (rebound after the shock), and withstanding (resist the shock). Tobin (1999) suggests that resilience is adopted in three ways: to mitigate (emphasising a reduction of exposures and risks); to recover (accepting that not all the shocks can be eliminated and thus embraces post-disaster

2 UNDRR (2019) defines resilience as "The ability of a system, community or society exposed to hazards to resist, absorb, accommodate, adapt to, transform and recover from the effects of a hazard in a timely and efficient manner, including through the preservation and restoration of its essential basic structures and functions through risk management". 
actions); and to instigate structural changes in society and institutions based on the importance of situational and cognitive factors. From a holistic or a broader systems approach (e.g. Lizarralde et al., 2015), resilience needs to be considered in multiple sectors of intervention, including emergency action, environmental protection, urban development and, as argued here, cultural heritage.

\section{Integration of cultural heritage requirements into DRM}

In the context of heritage, "resilience may be understood as the ability to experience shocks while retaining heritage values" (Australia State of the Environment 2011: 780). However, it is argued that resilience should be much more than 'retention' of heritage values and more about the capacity for cultural values to thrive (Ravankhah et al. 2017). To achieve this Jigyasu (2016) suggests that support (i.e. finance, technical support, training, skills) should be provided for local economic development to reduce vulnerability to disasters and build resilience through, for example, opportunities for livelihood regeneration. Within the heritage community, any stakeholders involved in decision making related to conservation, and those who influence the delivery and management of heritage sites, should be increasingly asked to respond simultaneously to the challenges posed by DRM. Discussing reconsideration of mitigation in heritage conservation, Boccardi (2015, p. 94) states that "in the new circumstances, the heritage paradigm should thus be reassessed by dissolving the artificial boundaries that kept it for so long segregated from the nonheritage". The current holistic approaches to heritage, such as the Historic Urban Landscape (HUL) approach, can for instance, better facilitate a proactive heritage role in disaster resilience planning. The HUL approach emphasises the intangible socio-cultural and economic patterns of community associated with cultural heritage on one side, and broader public-private stakeholder network and institutions on the other. Within DRM planning, instead of mainly focusing on the regional geographical and hydro-meteorological conditions, such an approach could contribute to reducing non-structural vulnerability on which disaster resilience greatly relies (Ravankhah et al. 2017).

However, it should be noted that heritage can also be viewed as an obstacle for implementing disaster mitigation policies or recovery plans. The European Parliament Committee Report on 'Protecting the Cultural Heritage from Disasters' (Drdacky, 2007, p. iii) realised that “...effective risk management of cultural assets is rare because of inadequate understanding of the assets, failure to calculate the true cost of loss and damage, and difficulty in putting a value on the non-market nature of many cultural heritage values". In more operational terms (and as observed by Menoni (2001), post-disaster responses and reconstruction efforts are overly influenced by a political and economic will to 'reconstruct quickly' (with the misguided belief that this will help society to 'recover'). Under these circumstances $\mathrm{CH}$ requirements are rarely put at the centre of reconstruction and ultimately the role of $\mathrm{CH}$ in the attainment of physical or social resilience is not well considered. It has also been noted that while the Sendai Framework on DRR clearly recognizes the importance of protecting and drawing upon heritage as an asset for resilience, there remain challenges to implement this policy, due to lack of capacities at international, national and local levels and the need to establish the necessary institutional mechanisms that are supported by data collection and monitoring (Dean \& Boccardi, 2015). The following section discusses heritage contributions to the DRM system that may cause challenges while bringing opportunities for increased disaster resilience.

\section{Previously acknowledged challenges for increased disaster resilience}

Previous studies on the specific subject of how the disaster resilience of heritage sites can be improved have been limited or conducted at a high strategic level (lacking assessment of a suitably broad range of cases). Some of the key challenges identified in previous studies are summarised thus:

\section{a. Multi-sector cooperation for risk preparedness and recovery}

Timely and effective reactive measures (i.e. emergency management) are not sufficient for keeping the built environment safe; it is vital to deal with hazards and threats proactively, with a broad range of stakeholders being involved, and to ensure interaction among them (Bosher and Chmutina, 2017). While DRM seeks to maximise safety through enhancing structural and non-structural performance, heritage conservation aims to keep a balance between safety and value. Heritage conservation principles, such as 'minimal changes to significant fabric and use' as advocated in key ICOMOS doctrinal texts play a vital role in formulating 
adequate disaster mitigation strategies to retain a balance between safety and heritage values. Multistakeholder cooperation, if not synchronised adequately in advance, may result in delaying the recovery process due to potential conflicts of perceptions, expectations and capacities of the sectors engaged in the process (Aysan and Davis, 1993). To ensure that cultural heritage is considered in multi-dimensional disaster resilience planning, raising awareness of heritage values among stakeholders involved in DRM should be encouraged, while increasing their competencies in dealing with cultural heritage through mitigation, preparedness, response and recovery strategies.

\section{b. Multi-assessment tools in decision making procedures}

Methodologies to assess loss of value, which demands a qualitative and systematic multi-risk analysis are still extremely complex (Ravankhah and Schmidt, 2014). This is particularly true of World Heritage properties, for which loss of Outstanding Universal Values (OUV) as well as associated conditions of authenticity and integrity should be adequately estimated within risk assessment procedures. When using a more holistic approach, viewing heritage as a source of resilience should be linked to three different assessment tools: Disaster Risk Assessment, Climate Change Impact Assessment, and Heritage Impact Assessment (HIA). ${ }^{3}$ With respect to implementation of DRM policies in historic environments, for example, new challenges may emerge regarding appropriate mitigation measures (e.g. flood control embankments, urban drainage system, and fire prevention installations) that do not negatively impact the heritage values. Such considerations should be explored earlier in the planning procedure, through multiple risk assessment and weighing risk reduction and heritage protection strategies in a multi-criteria decision-making context.

\section{c. Post-disaster reconstruction and new development vs. maintaining cultural heritage}

Within post-disaster rehabilitation and recovery, there is a unique opportunity for transformation and modernisation, but heritage properties are expected to be preserved with minimal change in order to retain their values and authenticity. This might be compromised for individual monuments, but heritage buildings that exist in a context of a non-heritage built environment (e.g. in rapidly developing urban areas) cannot be overlooked, since failure in some elements will result in declining resilience of the whole system (Weise, 2016).

Therefore, while previous studies have found that there are a few already acknowledged challenges to increasing the resilience of cultural heritage, as already noted, previous studies on this topic have tended to be related to a limited number of specific cases or conducted at a high strategic level. This paper sets out to add some richness to the evidence base by assessing 80 case studies, drawn from a variety of countries, presenting an overview of different types of impacts and challenges and dealing with a variety of hazards and threats; in doing so this paper will identify the types of strategies being adopted to mitigate the risks, some of which could be transferred across cultural and geographical contexts.

\section{METHODOLOGY}

This paper presents an analysis of detailed case studies that have been presented by participants on UNESCO's International Training Course (ITC) on Disaster Risk Management of Cultural Heritage. The ITC is organised by the Institute of Disaster Mitigation for Urban Cultural Heritage (R-DMUCH) at Ritsumeikan University, Kyoto, Japan. R-DMUCH has hosted the UNESCO Chair ITC since 2006, attracting over 115 participants (through a competitive selection process) from mainly low- and middle-income countries. The participants that submitted applications to participant in the course were mainly selected by experts from international, national and local authorities, academics and the practitioners of DRM or in CH conservation field. Every participant needed to select one case study site from their own country; ideally this should be a $\mathrm{CH}$ site where there would be a high possibility of the participant to implement their DRM plans on the site. There was also a requirement that the $\mathrm{CH}$ site should be vulnerable to one or more natural hazards. At the

\footnotetext{
${ }^{3}$ HIA is "a process of identifying, predicting, evaluating and communicating the probable effects of a current or proposed development policy or action on the cultural life, institutions and resources of communities ... with a view to mitigating adverse impacts and enhancing positive outcomes" (Sagnia and INCD, 2004: 6).
} 
end of each course, the participants have been required to present a detailed case study aimed at preparing an outline DRM plan for a specific heritage site in their country. This paper reports on an in-depth analysis of 80 of these detailed case studies; from 45 different countries (36 of which are classified as low/middle income nations), see Figure 4 for a map of the case study locations (which are listed in Table A in the Appendix). 50 of the 80 case studies assessed are designated as UNESCO (mainly cultural) heritage sites.

\section{Analysis of the case studies}

Overall a total of 115 participant case studies have been presented during the ITC course. Each of the case studies were tasked with providing a summary report and illustrative MS Power Point presentation slides, that were broken down into the following themes: a) Introduction (i.e. location and context), b) Heritage attributes of the site (background and specific attributes), c) Site risk assessment (identified hazards, threats and vulnerabilities), d) Scenario (of what could go wrong) and e) Risk management plan (setting out possibly mitigation, preparedness and recovery options). Each of the cases where then qualitatively assessed using thematic coding (based on the key themes and sub-themes included for each study). In the few cases where the report and/or presentation slides were lacking the relevant information, those case studies were excluded from the analysis, which resulted in 80 out of the 115 case studies being included in the analysis presented here. Of these 80 case studies, 50 of them are listed on the UNESCO World Heritage List under the Cultural Heritage classification ${ }^{4}$. Out of the 80 cases reviewed, 68 are in urban or peri-urban contexts, with only 9 in remote/rural locations (i.e. archaeological sites such as Volubilis, Chan Chan and Mohenjo-Daro). Four of the cases included in this review are classified by UNESCO as 'In danger'.

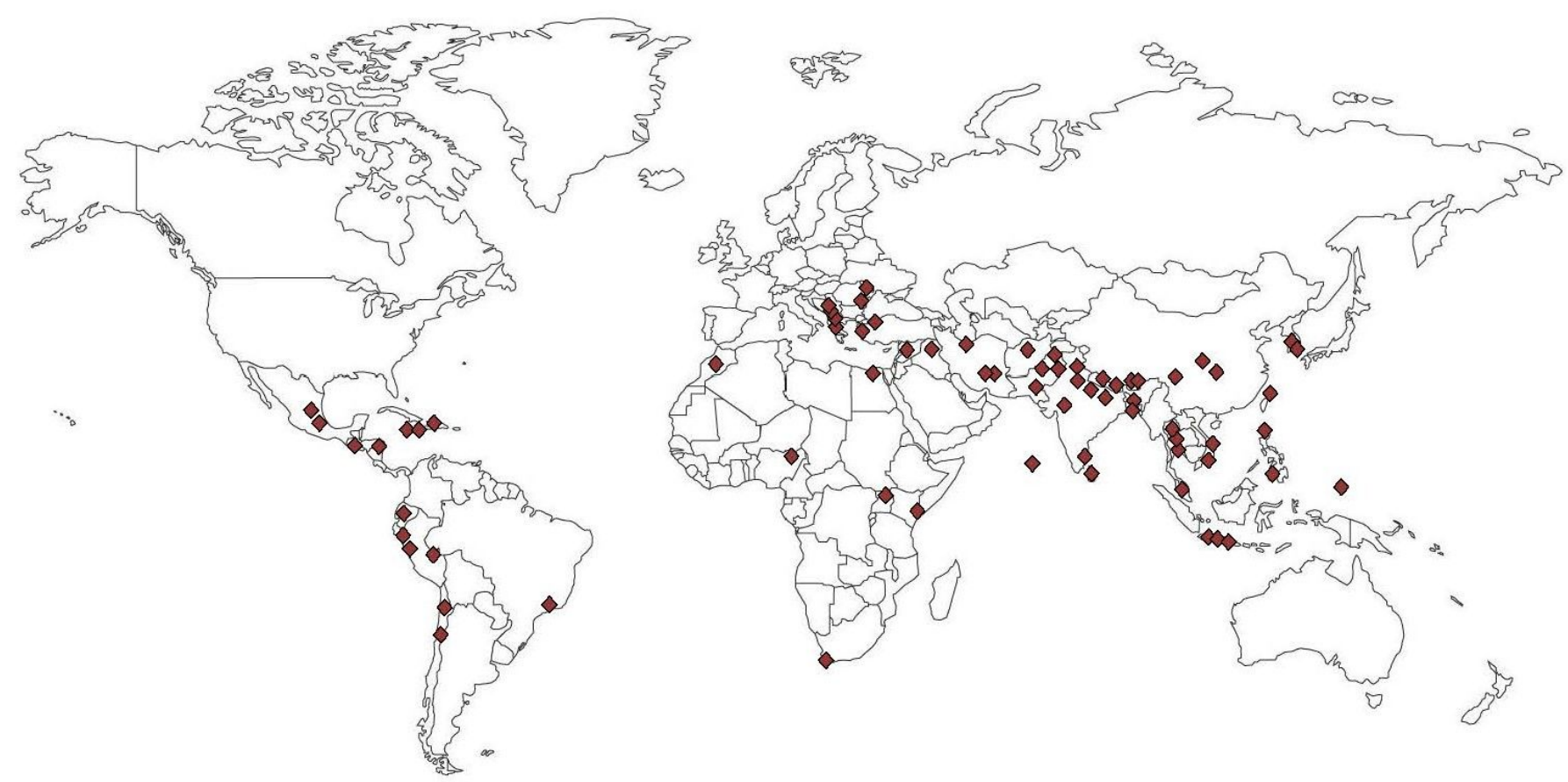

Figure 4: Locations of the 80 case studies analysed for this study

\section{RESULTS AND DISCUSSION}

\section{Key hazards and threats}

The frequency of hazards and threats are summarised in Table 1; most case studies reported multiple hazards and threats. Across the geographical regions, the most prevalent hazards likely to be encountered

\footnotetext{
${ }^{4}$ Based upon UNESCO listings on $11^{\text {th }}$ April 2018, see https://whc.unesco.org/en/list/
} 
were earthquakes, floods and fire. It is noticeable that in many of the Asian case studies, there are multiple earthquake related hazards listed for nearly all of the case studies, this category includes earthquakes (directly) and earthquake related (i.e. indirect such as tsunamis, landslides and fires) in this category. Most of the fourteen case studies in the Americas, mainly in South America but also including Central America and the Caribbean islands, encountered earthquakes, floods and fires. A high proportion of threats from Urbanisation was experienced in the Americas, in 4 out of 14 cases. Flooding and fire (natural and human induced) were the most prevalent hazards and threats in the seven African case studies, and vandalism and theft were experienced in nearly half of the African case studies. It is interesting to note that 'climate change' was only considered as a contributory problem in 11 out of the 80 case studies (although it should be acknowledged that climate change may be influencing the prevalence of floods and storms in a way that may have been too discreet for the course participants to have acknowledged).

Table 1: Overview of key hazards and threats encountered on 80 case study sites (2006-2016)

\begin{tabular}{|c|c|c|c|c|c|c|c|c|c|c|c|}
\hline \multicolumn{12}{|c|}{ Frequency of key hazards and threats reported by region } \\
\hline Region (cases) & E'quake & Flood & Fire & Storm & $\begin{array}{l}\text { Land- } \\
\text { slide }\end{array}$ & $\begin{array}{c}\text { Vandal/ } \\
\text { theft }\end{array}$ & $\begin{array}{l}\text { Climate } \\
\text { Change }\end{array}$ & $\begin{array}{c}\text { Warl } \\
\text { terrorism }\end{array}$ & $\begin{array}{l}\text { Urban- } \\
\text { isation }\end{array}$ & Volcano & Other \\
\hline Africa (\#7) & 2 & 6 & 7 & 2 & 1 & 3 & 2 & 1 & & & 2 \\
\hline Americas (\#14) & 13 & 11 & 10 & 9 & 9 & 2 & 2 & 1 & 4 & 2 & 3 \\
\hline Asia (\#44) & 34 & 30 & 25 & 14 & 8 & 10 & 4 & 4 & 3 & 5 & 11 \\
\hline Europe (\#6) & 8 & 6 & 8 & 1 & 5 & & 2 & 1 & & & 5 \\
\hline Mid. East (\#7) & 2 & 2 & 2 & 2 & 1 & & & 2 & 1 & & 1 \\
\hline Pacific (\#2) & 1 & 2 & 3 & 3 & 1 & 2 & 1 & & & & 1 \\
\hline Total (\#80) & 60 & 57 & 55 & 29 & 25 & 17 & 11 & 9 & 8 & 7 & 23 \\
\hline
\end{tabular}

Note: 'Landslide' category only includes direct landslide related impacts (not those indirectly triggered by earthquakes)

'Other' category includes pollution, tourism, crowd control, termites and transportation accidents

When the 80 case studies are segregated into those that are currently listed by UNESCO (\#50) and those that are not listed (\#30), there are some more interesting observations (Table 2). It is apparent that seven of the eight case studies that listed urbanisation as a threat are heritage sites that are not UNESCO listed $(23 \%$ of the unlisted cases compared to $2 \%$ of the UNESCO listed cases). Also 10 out of the 17 cases of vandalism/theft are in unlisted heritage sites (33\% of the unlisted cases compared to $21 \%$ of the UNESCO listed cases). Whilst acknowledging the small sample size, this may indicate that UNESCO listed status might play a positive role in helping such sites proactively reduce or even eliminate human induced threats such as encroachment of urban development and contribute towards improving the security of the sites. Conversely, the UNESCO listed sites experienced slightly greater problems with 'tourism' and 'crowd control' (in the 'Other' category); this may highlight some of the negative impacts of being listed as important by UNESCO. Thus, possessing 'UNESCO listed status' can have positive and negative impacts on the sites.

Table 2: Overview of key hazards and threats encountered on 80 case study sites, by listed status

\begin{tabular}{|c|c|c|c|c|c|c|c|c|c|c|c|}
\hline \multicolumn{12}{|c|}{ Frequency of key hazards and threats reported by listed status } \\
\hline Listed status & E'quake & Flood & Fire & Storm & $\begin{array}{l}\text { Land- } \\
\text { slide }\end{array}$ & $\begin{array}{c}\begin{array}{c}\text { Vandal/ } \\
\text { theft }\end{array} \\
\text { ton }\end{array}$ & $\begin{array}{l}\text { Climate } \\
\text { Change }\end{array}$ & $\begin{array}{c}\text { Warl } \\
\text { terrorism }\end{array}$ & $\begin{array}{l}\text { Urban- } \\
\text { isation }\end{array}$ & Volcano & Other \\
\hline UNESCO listed (\#50) & 36 & 38 & 31 & 22 & 17 & 7 & 8 & 6 & 1 & 5 & 22 \\
\hline Not listed (\#30) & 24 & 19 & 24 & 7 & 8 & 10 & 3 & 3 & 7 & 2 & 1 \\
\hline Total (\#80) & 60 & 57 & 55 & 29 & 25 & 17 & 11 & 9 & 8 & 7 & 23 \\
\hline
\end{tabular}

\section{Typical impacts and challenges to heritage sites}

Only four of the sites assessed in this study were ascribed by UNESCO on the 'List of World Heritage in Danger'; namely the Buddha in Bamyan Province (Afghanistan), Chan Chan (Peru), Alhusen Castle (Syria) and the Tombs of Buganda Kings (Uganda). It is not being suggested in this paper that the other $\mathrm{CH}$ case study sites included in this assessment may need to be inscribed on the 'List of World Heritage in Danger', 
however we do think it is interesting to reflect upon the extent to which these case studies sites are at risk. On that matter, it is beyond the scope of this paper to provide a detailed analysis of the specific tangible impacts (or indeed intangible impacts that were not prominent in the case studies reports) of the hazards and threats for each of the 80 case study locations. Nonetheless, the key hazards/threats have been summarised in Table $A$ in the appendix. It has also been possible to draw out the most common tangible impacts across the case studies, as summarised in Table 3.

Table 3: Summary of the key tangible impacts to the case study sites

\begin{tabular}{|c|c|}
\hline Hazards & Key tangible impacts \\
\hline $\begin{array}{l}\text { Such as... } \\
\text {-Earthquakes } \\
\text {-Floods } \\
\text {-Fire } \\
\text {-Storms } \\
\text {-Landslides } \\
\text {-Volcanoes } \\
\text {-Climate change }\end{array}$ & $\begin{array}{l}\text { - } \text { Destruction/damage to structures (direct) } \\
\text { - } \quad \text { Destruction/damage to building contents/collections (direct) } \\
\text { - } \quad \text { Gestruction/damage to supporting infrastructure (indirect) } \\
\text { - } \quad \text { Blocking of access/egress routes to sites (i.e. for emergency access) } \\
\text { - Evacuation of sites (leaving } \mathrm{CH} \text { prone to theft) } \\
\text { - } \quad \text { manges to weather increasing/decreasing moisture (leading to ground } \\
\text { - } \quad \text { Changements and affecting building/contents materials) } \\
\text { - Inappropriate interventions (to address hazard mitigation) }\end{array}$ \\
\hline Threats & Key tangible impacts \\
\hline $\begin{array}{l}\text { Such as... } \\
\text {-Vandalism/theft } \\
\text {-War/terrorism } \\
\text {-Rapid urbanisation } \\
\text {-Stampedes/crowd } \\
\text { management }\end{array}$ & $\begin{array}{l}\text { - Destruction/damage to structures (direct) } \\
\text { - Destruction/damage to building contents/collections (direct) } \\
\text { - } \text { Damage to/stress on supporting infrastructure (indirect) } \\
\text { - } \text { - Low levels of site/CH asset security } \\
\text { - } \mathrm{Coorly} \mathrm{regulated} \mathrm{construction} \mathrm{affecting} \mathrm{CH} \text { attributes } \\
\text { - Increases in air/water pollution affecting materials } \\
\text { - } \quad \text { Incmolition of } \mathrm{CH} \text { for newly built developments } \\
\text { - Reduction in tourist numbers (that are poorly managed) }\end{array}$ \\
\hline
\end{tabular}

In all the cases assessed, there was either examples of, or great potential for, serious deterioration of materials, structure and/or ornamental features, architectural and/or town-planning coherence and/or serious deterioration of urban or rural space, or the natural environment. These are problems that could lead to the significant loss of heritage values. It is especially interesting to note that it is not only the direct impacts of hazards and threats that should be considered, but the (often overlooked) secondary impacts of hazards should also be a key consideration when managing 'at risk' sites; these secondary hazards include fire and landslides (i.e. after earthquakes), problems with crowd evacuation and emergency access (in the event of floods, fire and earthquakes) and increases in pests and mould (due to changes in the climate and due to long term impacts of floods or storms). Some of the secondary threats observed across the case studies, included increases in theft and (poorly managed) tourist numbers, and increases in air/water pollution because of rapid and poorly managed urbanisation.

\section{Key challenges}

It is increasingly being appreciated that effective disaster risk management should not be focused on the impacts of problems as that can lead to an overly reactive approach to how the risks are managed (Bosher and Chmutina, 2017). Therefore, it is important to ascertain what the underlying vulnerability factors were in the case studies that may have led to the observed problems. To ensure that an overly technocratic approach is not taken, six 'challenge' categories (including social, cultural, environmental as well as technical factors) have been utilised. In all the cases assessed, multiple challenges were experienced, and some challenges were more prominent than others (see Table 4). The most prevalent challenges were technical $(90 \%)$, Infrastructure (74\%), and Governance (71\%). Interestingly 'financial' was only considered as a key challenge 
in $29 \%$ of the 80 cases studies. When looking at the different challenges according to listed status, it is worthwhile noting that there were not any major differences in the prevalence of the different challenges except for 'social', which appears to be a slightly larger challenge for UNESCO sites (66\%) than unlisted sites $(43 \%)$.

Table 4: Overview of the frequency (and \%) of specific challenges identified on the case study sites

\begin{tabular}{|l|c|c|c|c|c|c|c|}
\cline { 2 - 7 } \multicolumn{1}{c|}{} & Technical & Environment & Infrastructure & Financial & Social & Behavioural & Governance \\
\hline Listed $(\# 50)$ & $44(88 \%)$ & $28(56 \%)$ & $36(72 \%)$ & $15(30 \%)$ & $33(66 \%)$ & $22(44 \%)$ & $37(72 \%)$ \\
\hline Not listed $(\# 30)$ & $28(93 \%)$ & $16(53 \%)$ & $23(76 \%)$ & $8(27 \%)$ & $13(43 \%)$ & $11(36 \%)$ & $20(67 \%)$ \\
\hline Total $(\# \mathbf{8 0})$ & $\mathbf{7 2}(\mathbf{9 0} \%)$ & $\mathbf{4 4 ( 5 5 \% )}$ & $\mathbf{5 9 ( 7 4 \% )}$ & $\mathbf{2 3 ( 2 9 \% )}$ & $\mathbf{4 6 ( 5 8 \% )}$ & $\mathbf{3 3 ( 4 1 \% )}$ & $\mathbf{5 7}(\mathbf{7 1} \%)$ \\
\hline
\end{tabular}

These challenges are explained below with some examples of case studies where the specific challenges are particularly prominent.

- Technical: mainly problems related to the inherent vulnerability of traditional materials used, deterioration of structure or materials, lack of maintenance and/or in appropriate renovation/repair, and low levels of traditional skills. Nine out of ten of the case studies experienced these problems, with prime examples of this challenge were found in Gjorakastra (Albania), Mompox (Colombia), Levuka (Fiji) and Bam (Iran).

- Environmental: related to problems associated with climatic conditions (some of which have changed over time), location in hazard prone areas, impacts of pests/animals and pollution (air/water/ground). Some key examples of this included Taoping Village (China), Coral Stone Mosques (Maldives), Rohtas Fort (Pakistan) and Hue Citadel (Vietnam).

- Infrastructural: related to lack of infrastructure (i.e. to cope with traffic, excess water, sewerage), ageing services (i.e. old/dangerous power supplies), narrow access roads and the impact of inappropriate neighbouring developments. Stone Town (Tanzania), Shimla (India), Tashichhodzong (Bhutan), Kandy (Sri Lanka) and Bagan (Myanmar) were some key examples experiencing this challenge.

- $\quad$ Financial: is related to direct lack of financial support, the deleterious impacts of too much tourism, but also including the constraints of the costs of appropriate hazard mitigation and insurance mechanisms. Puebla (Mexico), Izmir (Turkey), Sto Nino Shrine and Museum (Philippines) and the Old City of Mostar (Bosnia and Herzegovina) were the cases where this issue was especially problematic.

- Social: is largely related to low appreciation of heritage values by local communities, land tenure and livelihood conflicts, misuse of sites (vandalism, looting, littering) and impact of external visitors (tourists). Mosque City of Bagerhat (Bangladesh), Qhapaq Nan (Chile), San Antonio del Cerro de Oro de Zaruma (Ecuador), National History Park (Haiti), and Kotagede (Indonesia) are examples of where these social challenges have been particularly prevalent.

- Behavioural: related to constraints of working in disciplinary siloes (i.e. in urban management/ development and in the heritage sector), differing values of heritage attributes by different stakeholders and religious/cultural practices (i.e. incense/candle burning). Prime examples of this challenge included the Buddha in Bamyan Province (Afghanistan), Bangrakam Amphibious Village (Thailand), Melaka Town (Malaysia) and Fatehpur Sikri (India).

- Governance: these problems include lack of appropriate (integrated) policies and regulations, overly technocratic approaches, pressures of development and illegal or uncontrolled development, low levels of coordinating and emergency preparedness/response capacity. Nearly three quarters of the case studies highlighted problems with governance issues impeding effective coordinated risk management of sites, but these matters were especially problematic in Lamu (Kenya), El Tajin (Mexico), Bagan (Mayanmar), Sukur (Nigeria), Cusco (Peru), Tombs of Buganda Kings (Uganda), Stone Town (Tanzania) and Wangduephodrang Dzong (Bhutan).

\section{Possible ways forward}


The case studies provided a wealth of useful information related to how some of these challenges might be addressed in the future. Some generic examples of how these challenges could be addressed include:

- Technical: central to addressing this challenge is the need to protect and utilise traditional construction and craft skills and to ensure that maintenance and the use of locally available materials is supported; through investment in skills training and sourcing appropriate materials. Capacity building for local artisans, builders and conservation practitioners is critical.

- Environmental: the case studies acknowledged that this is a tough problem to deal with as there are increasing cases where $\mathrm{CH}$ assets were built at a time when the climate/weather was quite different to that being experienced today. Some possible ways forward would be to monitor sites to measure environmental changes/sensitivities and to learn from good practice from other $\mathrm{CH}$ heritage sites that experience similar problems. In relation to dealing with sites in hazard prone areas, it would be useful to take a broader/neighbourhood/catchment approach to dealing with the hazards (i.e. looking at how flood risk can be addressed upstream of a site rather than at the exact location of the site) or indeed the use of nature-based approaches to risk management.

- Infrastructural: the management, maintenance and upgrading of key (especially urban) infrastructure is a major problem in heritage and non-heritage contexts globally. It was noted in the case studies that many of the major infrastructure weaknesses tend to be beyond the capabilities/remits of $\mathrm{CH}$ sites to deal with (i.e. inadequate drainage, ageing/unsafe electricity supplies and overcrowded roads). The only way to really address this challenge is to work hand-in-hand with local government and with the agencies (and possibly private sector businesses) that are responsible for keeping the infrastructure functioning at the levels required. As part of this work, strategies are needed to support wider stakeholder engagement. Additionally, there is a pressing need to develop emergency access scenarios that can identify pinch points and improve access for emergency services.

- $\quad$ Financial: as noted above, 'financial' was the least prevalent challenge on the case studies. Nonetheless, it was acknowledged that there is scope for improvements in how, for instance, the revenue from tourism can be used to protect $\mathrm{CH}$ or indeed help to develop DRM capacities.

- Social: the social issues encountered are invariably highly context specific. Central to many of the challenges encountered on the case studies, are the low levels of basic services (i.e. water, sanitation, healthcare, employment, education) for the local population (especially in the low- and middle-income countries where 36 of the cases were located). Generally, improvements to the basic services that underpin peoples' living conditions will help to alleviate many of the social issues (such as theft, littering and open defecation). Of course, addressing these problems is beyond the capabilities of $\mathrm{CH}$ practitioners but there are activities that can be undertaken to contribute positively to addressing this issue; for instance, developing awareness campaigns, especially with local communities and the business sector.

- $\quad$ Behavioural: these constraints were largely related to problems of working in disciplinary siloes and to a lesser extent the differing values of heritage attributes by different stakeholders and religious/cultural practices. There is a growing movement of inter-disciplinary and multi-disciplinary activities where the various stains of $\mathrm{CH}$ practice as well as other sectors such as urban management and disaster risk management are working together to co-produce frameworks and solutions to break out from the previous disciplinary siloes. Still there is more room for improvement and more scope to develop integrated DRM and $\mathrm{CH}$ plans as part of master planning and to maximise the links between tourism, $\mathrm{CH}$ and DRM.

- $\quad$ Governance: these challenges were prevalent in $71 \%$ of the case studies. It is widely acknowledged that all the key stakeholders need to work together, this includes legislative approaches such as tighten building regulations and planning policy (plus effective enforcement) so that the negative impacts of urbanisation on $\mathrm{CH}$ can be minimised. To help instigate these changes there may be a need to provide evidence of how $\mathrm{CH}$ is being adversely affected by urbanisation and to develop a database of evidence of good (and poor) practice.

\section{CONCLUSIONS}

It is widely appreciated that cultural heritage sites are not only important components of a country's identity but can also be important drivers of economic sustainability and central to supporting societal resilience. 
However, an increasing number of disastrous events have highlighted the vulnerability of cultural heritage worldwide. It is noted that there has so far been a lack of research on how multiple hazards and threats affect $\mathrm{CH}$ sites and what types of strategies are typically adopted to manage the myriad risks. This paper provides a broad but solid foundation for future research. Thus, this study aimed to identify the key natural hazards and human-induced threats to 80 cultural heritage sites around the world and in doing so has highlighted the typical types of impacts to the tangible components of $\mathrm{CH}$.

This analysis has assessed the range of structural and non-structural strategies being adopted to mitigate or in some cases eradicate the risks. It demonstrates that whilst the issues are indeed complex (and typically context specific), there are nonetheless many similarities, to the problems encountered and approaches to risk reduction, regardless of the location. It is these key messages that we feel can provide a useful catalyst for future research and more effective risk management activities across $\mathrm{CH}$ sites globally; at least this analysis can provide the basis for further debates on the topic.

\section{Key messages}

The risks to $\mathrm{CH}$ sites tend to come from multiple hazards and threats: All the sites analysed included more than one hazard/threat as an observed/experienced problem, this indicates the folly of adopting approaches to risk management that focus on a specific type of hazard/threat rather than considering a multihazards/threats approach to DRM.

Disaster risk management can often be too reactive: Whilst DRM of $\mathrm{CH}$ is being promoted and the number of initiatives is growing, many of these initiatives are addressing a specific disaster risk management phase (e.g. response and recovery). There are currently not enough initiatives that proactively include hazard mitigation/retrofitting into $\mathrm{CH}$ (ideally before a disaster has occurred).

Overly technocratic approaches are missing the point: This paper indicates that although finance and technical challenges exist, it tends to be the non-technical challenges (such as governance, behaviour, inequality and marginalisation) that exacerbate the risks faces by $\mathrm{CH}$ sites irrespective of contextual nuances.

UNESCO status was not a key determinant in level of risk: It is acknowledged that a review of 80 sites (out of over 1,000 UNESCO sites) may only be scratching the surface of the problem, thus the following observations should be treated with caution. Overall it appears that UNESCO status does not play a major role in the extent to which sites are exposed to risks. It appears from this analysis that UNESCO listed status can provide a fine balance between a) negative impacts associated with attracting increased visitors and thus added developmental pressures to the site and b) playing a positive role in helping sites at risk of vandalism/theft to proactively address such problems (possibly due to improved security fencing around the site perimeter and higher presence of security personnel that listed status might support).

Challenges for research and practice: It is clear that the domain of DRM for $\mathrm{CH}$ is under-researched, in particular when it comes to finding evidence about best practices and failures, as well as what might be viewed as addressing 'non-traditional' threats such as urbanisation and the secondary hazards and threats associated with poorly regulated urban expansion. Table 5 provides an overview of the potential research areas and highlights the complexity of DRM for $\mathrm{CH}$ - and the criticality of finding answers to these questions because - as emphasised by Aparna Tandon, one of the ITC trainers, - "culture cannot wait".

Table 5: Challenges in research and practice that need addressing in a DRM and CH context

\begin{tabular}{|l|l|l|}
\hline Challenges & \multicolumn{2}{|c|}{ Suggested areas for Research and Practice } \\
\hline $\begin{array}{l}\text { Dealing with multiple } \\
\text { hazards/threats }\end{array}$ & - $\begin{array}{l}\text { Structural diagnostics that can help understand key risks and prioritise interventions } \\
\text { - Sewage and drainage can create often hidden vulnerabilities; mapping of these } \\
\text { 'underground' vulnerabilities is required }\end{array}$ \\
& $\begin{array}{l}\text { Blue Green (nature-based) approaches to risk management in flood prone areas } \\
\text { - Development of hand pulled 'fire carts' for narrow streets }\end{array}$ \\
\hline
\end{tabular}




\begin{tabular}{|c|c|}
\hline $\begin{array}{l}\text { Dealing with multiple } \\
\text { stakeholders (some } \\
\text { obvious and others less } \\
\text { so) }\end{array}$ & $\begin{array}{l}\text { - Stakeholder mapping (inc. influence and interest considerations) } \\
\text { - Develop strategies for wider stakeholder engagement } \\
\text { - Drills and awareness campaigns, esp. with tourists and local communities/business } \\
\text { sector }\end{array}$ \\
\hline $\begin{array}{l}\text { Need to link } \mathrm{CH} \text { and } \\
\text { DRM policy and } \\
\text { practices }\end{array}$ & $\begin{array}{l}\text { - Develop integrated DRM and } \mathrm{CH} \text { plans as part of master planning } \\
\text { - Links between tourism, } \mathrm{CH} \text { and DRM - identify how tourists can play a positive role } \\
\text { - } \quad \text { Develop a database of evidence of good practice }\end{array}$ \\
\hline $\begin{array}{l}\text { Need to consider } \mathrm{CH} \\
\text { assets within broader } \\
\text { development context }\end{array}$ & $\begin{array}{l}\text { - Better integrated DRM approaches that include not just the site but surrounding } \\
\text { areas and local residents } \\
\text { - } \quad \text { Provide evidence of how } \mathrm{CH} \text { is being adversely affected by urbanisation } \\
\text { - } \quad \text { Provide evidence of how } \mathrm{CH} \text { can actually support sustainable urban development }\end{array}$ \\
\hline $\begin{array}{l}\text { Previous inappropriate } \\
\text { interventions (to repair } \\
\text { or maintain } \mathrm{CH} \text { ) }\end{array}$ & $\begin{array}{l}\text { - Develop database of evidence of good (and poor) practice } \\
\text { - } \quad \text { Capacity building for local artisans, builders and conservation practitioners } \\
\text { - Development of appropriate retrofitting interventions (design, materials, technology) } \\
\text { - Development of covert (and affordable) fire suppression systems }\end{array}$ \\
\hline $\begin{array}{l}\text { Pressures of urban } \\
\text { development }\end{array}$ & $\begin{array}{l}\text { - Emergency access: scenarios to identify pinch points and improve access for } \\
\text { emergency services } \\
\text { - Develop integrated DRM and } \mathrm{CH} \text { plans as part of master planning } \\
\text { - Where necessary tighten building regulations and planning policy (plus enforcement) }\end{array}$ \\
\hline Pressures from tourism & $\begin{array}{l}\text { - Find evidence of how revenue from tourism can be used to protect } \mathrm{CH} \text { or develop } \\
\text { DRM activities } \\
\text { - Development of crowd management strategies/tools } \\
\text { - } \text { Identify how tourists can play a positive role } \\
\text { Emergency access: develop scenarios to identify pinch points and improve egress } \\
\text { for tourists }\end{array}$ \\
\hline $\begin{array}{l}\text { Lack of capacity at the } \\
\text { local level (professional } \\
\text { and social) }\end{array}$ & $\begin{array}{l}\text { - } \quad \text { Capacity development (including community participation) } \\
\text { - Community involvement in delivering DRM for } \mathrm{CH} \\
\text { - } \mathrm{CH} \text { is not a priority in disasters; awareness as to why } \mathrm{CH} \text { needs protecting } \\
\text { - Training in the protection of moveable heritage }\end{array}$ \\
\hline
\end{tabular}

This paper does not, and has not set out to, answer all the questions about dealing with multiple hazards and threats on cultural heritage sites. However, it has provided useful insights from 80 case studies as a platform for further studies. This study has also provided suggestions for how practitioners and researchers may wish to ensure that the high level ambitious of the UN (i.e. the SDGs and Sendai) can become realities on the ground. Central to this agenda for research and practice is the requirement for DRM, CH and many other development practitioners to better understand not just what they can do for cultural heritage but importantly what cultural heritage can do for them.

\section{REFERENCES}

Alexander, D. (2013), 'Resilience and disaster risk reduction: an etymological journey', Natural Hazards and Earth System Sciences Discussions, Vol. 1, pp.1257-1284.

Australia and State of the Environment Committee 2011 (Australia). (2011), "Resilience of heritage", Australia state of the environment 2011: An independent report presented to the Australian Government Minister for Sustainability, Environment, Water, and Communities. Canberra: Dept. of Sustainability, Environment, Water, Population and Communities, pp. 780-783.

Australia ICOMOS (2000), The Burra Charter: The Australia ICOMOS charter for places of cultural significance 1999: with associated guidelines and code on the ethics of co-existence, Burwood, Vic: Australia ICOMOS. Available from: australia.icomos.org/wp-content/uploads/BURRA_CHARTER.pdf. 
Aysan, Y. and Davis, I. (1993), Rehabilitation and reconstruction, UNDP/DHA Disaster Management Training Programme.

Bahadur, A.V., Ibrahim, M and Tanner, T. (2010), The resilience renaissance? Unpacking of resilience for tackling climate change and disasters. Report for Strengthening climate resilience. Available from: http://community.eldis.org/.59e0d267/resilience-renaissance.pdf. [April 2018].

Bigio A. G., Ochoa M. C., and Amirtahmasebi R. (2014), Climate-resilient, Climate-friendly world heritage cities, World Bank, Washington DC

Boccardi, G. (2015), 'From Mitigation to Adaptation: A New Heritage paradigm for the Anthropocene', in Albert, M.-T. (2015). Perceptions of Sustainability in Heritage Studies, Walter De Gruyter, Boston.

Bosher L.S. (2014), 'Built-in resilience through Disaster Risk Reduction: Operational issues', Building Research \& Information, Vol. 42, No.2, pp. 240-254.

Bosher L.S. and Chmutina K., (2017), Disaster Risk Reduction for the Built Environment, Wiley, London

Brand, F.S., and Jax. K (2007), 'Focusing the meaning(s) of resilience: resilience as a descriptive concept and a boundary object', Ecology and Society, Vol. 12, No. 1, pp. 23-37.

Chmutina, K., Lizarralde, G., Dainty, A. and Bosher, L. (2016), 'Unpacking resilience policy discourse’, Cities, 58 , pp. $70-79$

Dean M. and Boccardi G., (2015). 'Sendai implications for culture and heritage in crisis response', Crisis Response, 10(4), 54

Drdacky, M. (2007), Protecting the Cultural Heritage from Natural Disasters, Policy Department Structural and Cohesion Policies, Culture and Education, European Parliament. Available from: www.europarl.europa.eu/.../IPOL-CULT_ET(2007)369029_EN.pdf

Francioni, F., (2008), The 1972 World Heritage Convention: An introduction, Oxford University Press, Oxford

Holling, C.S. (1973), 'Resilience and stability of ecological systems', Annual review of ecology and systematics, Vol. 4, pp.1-23.

Jigyasu, R., Murthy, M., Boccardi, G., Marrion, C., Douglas, D., King, J., O'Brien, G., Dolcemascolo, G., Kim, Y., Albrito, P. and Osihn, M. (2013), 'Heritage and Resilience: Issues and Opportunities for Reducing Disaster Risks', 4th Session of Global Platform for Disaster Risk Reduction, May, Geneva, Switzerland

Jigyasu, R., (2016), 'Reducing Disaster Risks to Urban Cultural Heritage: Global Challenges and Opportunities'. Journal of Heritage Management, 1(1), pp.59-67

Lizarralde, G., Valladares, A., Olivera, A., Bornstein, L., Gould, K. and Barenstein, J.D., (2015) 'A systems approach to resilience in the built environment: the case of Cuba'. Disasters, 39(s1).

Masuda K., Kim M., Mendoza Shimada O.K., Itaya N. and Yi M., (2009) 'Importance of international recognition on the risk of world cultural heritage sites located in earthquake zones', Journal of Disaster Mitigation for Historical Cities, Vol.3

Menoni, S. (2001) 'Chains of damages and failures in a metropolitan environment: some observations on the Kobe earthquake in 1995'. Journal of Hazardous Materials. 86(1-3). pp. 101-119.

OCHA, (2018), 'Humanitarian and Country Icons 2018', UN Office for the Coordination of Humanitarian Affairs, Available from https://reliefweb.int/report/world/humanitarian-and-country-icons-2018 [June 2019]

Ravankhah M., Chmutina K., Schmidt M. and Bosher L.S., (2017), 'Integration of Cultural Heritage into Disaster Risk Management: Challenge or Opportunity for Increased Disaster Resilience': In Albert M-T, Bandarin F., Pereira Roders A., (Eds.) Going Beyond - Perceptions of Sustainability in Heritage Studies No. 2, Volume 5 of the Heritage Studies Series, De Gruyter

Ravankhah, M. and Schmidt, M. (2014), "Developing Methodology of Disaster Risk Assessment for Cultural Heritage Sites", Proceeding of Residential Doctoral School (RDS) at 4th International Conference on 
Building Resilience, Salford Quays, UK, 8-10 September 2014, pp. 13-22. Available from: http://www.preventionweb.net/english/professional/publications/v.php?id=41475. [November 2017].

Sagnia, B. (2004), Framework for Cultural Impact Assessment, International Network for Cultural Diversity, UNESCO

Tobin, G. A (1999), 'Sustainability and community resilience: the holy grail of hazards planning?', Global Environmental Change Part B: Environmental Hazards, Vol.1 No.1, pp. 13-25.

UN (2015), Global Assessment Report on Disaster Risk Reduction. Available from: http://www.preventionweb.net/english/hyogo/gar/2015/en/home/. [December 2017].

UN System Task Team on the Post-2015 UN Development Agenda (2012), Realising the Future We Want for All, Report to the Secretary-General, United Nations, New York

UNDRR (2019), Terminology on Disaster Risk Reduction, UNISDR, Geneva, Switzerland. Available from: https://www.unisdr.org/we/inform/terminology [June 2019].

UNISDR (2015), Sendai Framework for Disaster Risk Reduction 2015 - 2030, United Nations. Available from: http://www.preventionweb.net/files/43291_sendaiframeworkfordrren.pdf. [September 2017].

UNESCO World Heritage Centre (2007), Strategy for Reducing Risks from Disasters at World Heritage properties, World Heritage Committee thirty first Session in Christchurch, New Zealand 23 June - 2 July 2007, UNESCO WHC, Paris. Available from: whc.unesco.org/archive/2007/whc07-31com-72e.pdf.

Weise K., (2016), "Damage and Continuity: Kathmandu Valley", Journal of the Development and Research Organization for Nature and Heritage (DRONAH), Special issue on Asia and Urban Heritage, Vol. 12

Worthing, D. and Bond, S. (2008), Managing built heritage: The role of cultural significance. Oxford, UK, Blackwell Pub. 


\section{APPENDIX}

Table A: Details of the $80 \mathrm{CH}$ case studies, listed status and summary of key hazards and threats for each site

\begin{tabular}{|c|c|c|c|}
\hline Country & Heritage case study site & $\begin{array}{c}\text { UNESCO } \\
\text { listed? } \\
\text { *'in danger' }\end{array}$ & Key hazards/threats \\
\hline Albania & Gjorakastra & $Y$ & \\
\hline Afghanistan & Buddha in Bamyan Province & $\mathbf{Y}^{*}$ & \\
\hline Bangladesh & Mosque City of Bagerhat & Y & \\
\hline- & Lal Bagh Fort, Dhaka & & \\
\hline Bhutan & Wangduephodrang Dzong & & \\
\hline- & Tashichhodzong & & \\
\hline Bosnia \& Herz. & The old city of Mostar & Y & \\
\hline Brazil & Tijuca forest sector (Rio) & $\mathrm{Y}$ & \\
\hline Chile & Qhapaq Nan & Y & \\
\hline- & Valparaiso & Y & \\
\hline China & Taoping village & Y & \\
\hline- & Dujiangyan & Y & \\
\hline- & Old Town of Lijiang & Y & \\
\hline Colombia & Mompox & Y & \\
\hline Ecuador & S. Antonio del Cerro de Oro de Zaruma & & \\
\hline Egypt & Historic Cairo & $Y$ & \\
\hline Fiji & Port town of Levuka (2013) & Y & \\
\hline- & Levuka (2012) & Y & \\
\hline Guatemala & City of Antigua Guatemala & $\mathrm{Y}$ & \\
\hline Haiti & National history park & $Y$ & \\
\hline Honduras & Tegucigalpa & & \\
\hline India & Shimla & & \\
\hline- & Mahaballpuram & $Y$ & \\
\hline- & Fatehpur Sikri & Y & \\
\hline- & Taj Mahal & $Y$ & 89 \\
\hline- & Champaner - Pavagadh & $\mathrm{Y}$ & \\
\hline
\end{tabular}




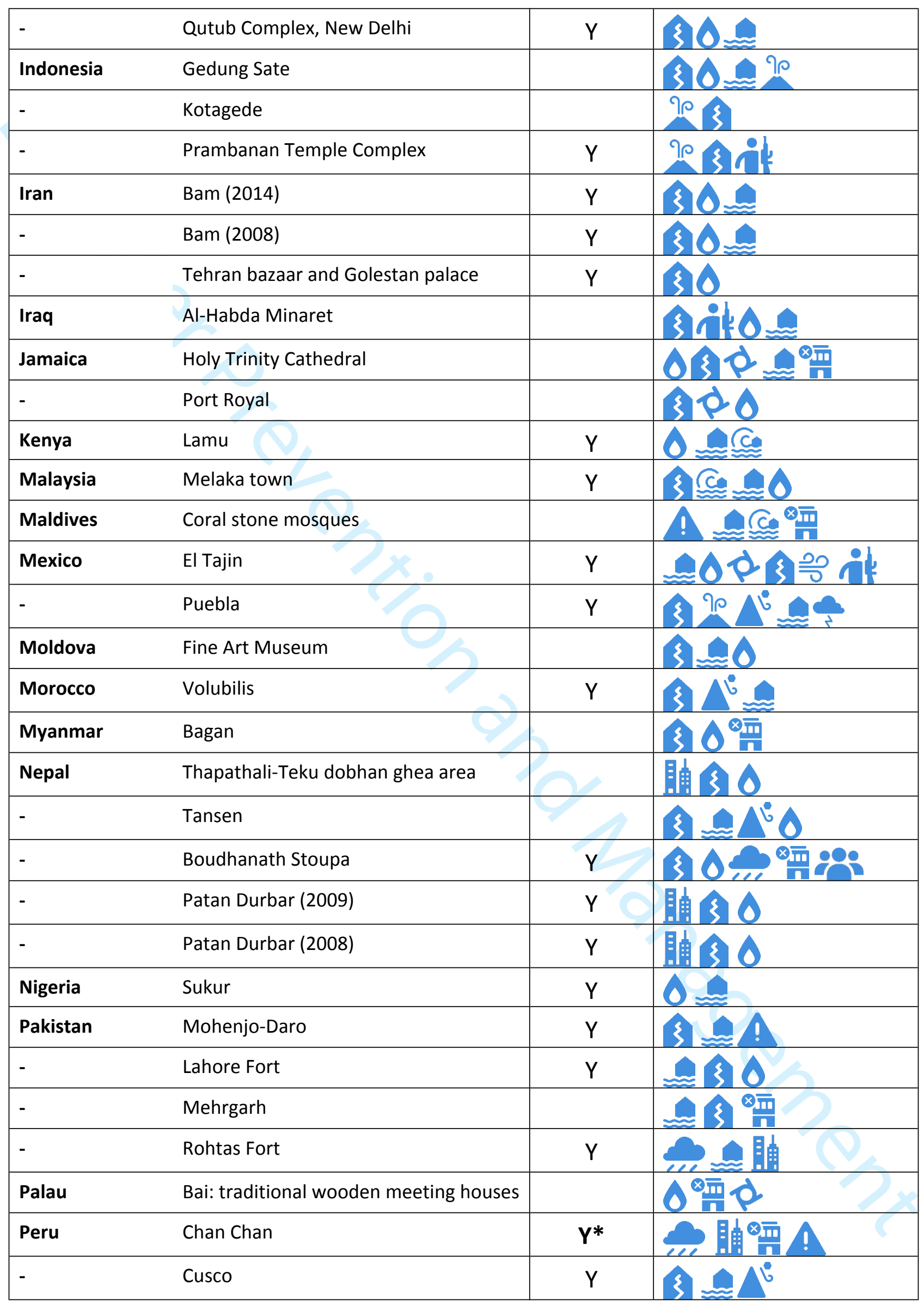




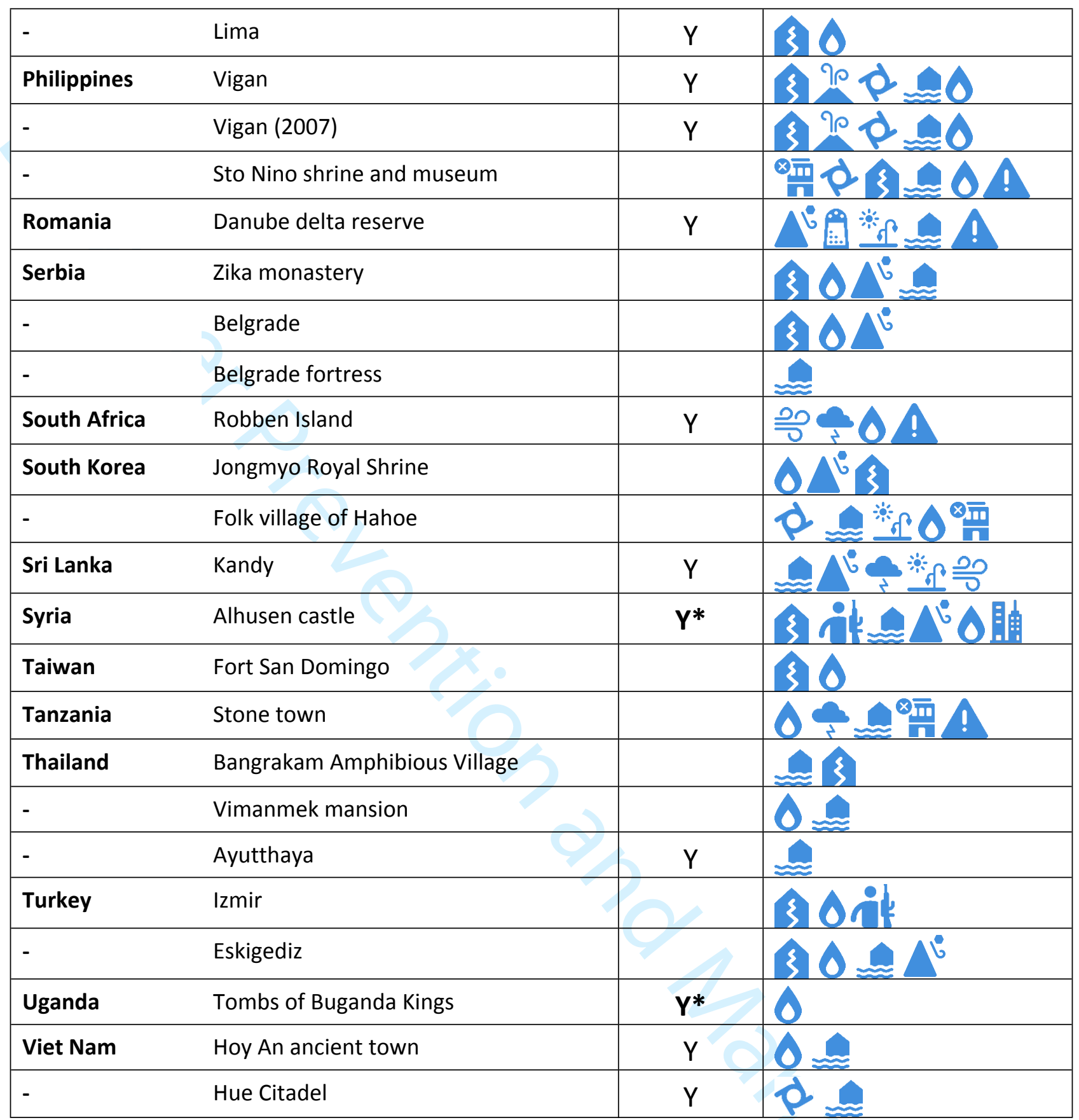

Key to symbols used:

\begin{tabular}{|c|l|c|l|}
\hline Symbol* & Type of hazard/threat & Symbol* $^{*}$ & Type of hazard/threat \\
\hline 1 & Climate change & & Rapid urbanisation \\
\hline & Crowd control/tourism management & & Salinity intrusion \\
\hline & Cyclone/Hurricane & Storm \\
\hline 3 & Earthquake & Strong winds \\
\hline 0 & Fire & $\approx$ & Tsunami \\
\hline
\end{tabular}


Volcano

War/terrorism

\begin{tabular}{|c|c|c|c|}
\hline D & Flood & & Volcano \\
\hline & Heavy rainfall & 14 & War/terrorism \\
\hline$\sigma^{6}$ & Landslide & & \\
\hline
\end{tabular}

Note: Source of the symbols used in this table is OCHA 2018 